\title{
The Effect of Honesty (Integrity) Auditors, Genders and Education Levels on Audit Quality
}

\author{
St.Ramlah ${ }^{1}$, Badriah Sappewali ${ }^{2}$, Ishak ${ }^{3}$, Erika Dwiyanti ${ }^{4}$, Grace T.Pontoh $^{5}$ \\ \{ramlah74putri@yahoo.com¹, badriah.sappewali@gmail.com², ishakhamzah476@yahoo.com ${ }^{3}$, \\ erikadwiyanti22@gmail.com ${ }^{4}$,gracetpontoh@fe.unhas.ac.id ${ }^{5}$ \}
}

STIE Tri Dharma Nusantara Makassar ${ }^{1,4}$, STIE Muhammadiyah Tanjung Redeb ${ }^{2}$, STIE Bongaya Makassar $^{3}$, Universitas Hasanuddin, Makassar ${ }^{5}$

\begin{abstract}
The purpose of this research is to find out the integrity quality of the Auditors, the quality of gender, and the quality of the education level on each auditor. The study uses primary data obtained from questionnaires and measurements using a Likert scale. The purposive sampling technique is used to get sampling. The auditors worked at the Inspectorate office on the Selayar islands are 37 of them as the sample on this subject. The test of multiple linear regressions is used on data analysis techniques. This research shows that: (1) There is a significant relationship between the Honesty (Integrity) of the Auditors towards the audit quality, (2) There is a significant relationship between Gender on the audit quality, and (3) There is a significant relationship between the education level of audit quality.
\end{abstract}

Keywords: Auditor integrity, gender, education level, audit quality.

\section{Introduction}

In the research, MGbame et al. (2012) said the relevance value on the audit depends on the quality of the audit [1]. However, Moizer (1997) notes that the assessment of the quality measurement index (quality) of audit services faces challenges because audit quality is usually not observable) [2]. An audit can be categorized as an exquisite type of trust according to Hay and Knechel (2011); therefore the Auditor gives responsibility for the company's financial statements by expressing the correct and impartial opinion but only in so far for the user of the financial statements on considering the assumption [3]. Houghton and Jubb (2003) state that audit services get value because of the client trust gets through the Auditor [4].

Kris et al. (2010) said that The market perception in regards to the value report of the Auditors, which is the outcome competency and the quality audit, is not only linear function from the competency of the Auditor and the independency Auditors and perception of independency Auditors [5]. By using this perception, the quality of the audit refers to the audit opinion credibility that is a measure of the trust value given by users of the information provided by the Auditor. According to MGbame et al. (2012) research found that gender is the cause that determines audit quality [1].

Research conducted by Gold et al. (2009) said that, on average, women, Auditors considered less competent compare to male Auditors [6]. There is also an opinion that woman Auditors tend to be careful, also pay attention to details, are more trusted, not lie. Which is another cause 
of audit quality besides gender is also caused by the level of education and honesty (Integrity) of the Examiner (Auditor).

Research relating to the level of education, gender, and honesty (Integrity) of the Auditor on the audit quality is: Findings by Ittonen and Peni (2009) support the idea that Auditor gender might be organize related to the audit quality [7]. In other research shows that the busyness of the Auditor (Auditor's education level) is negatively related (positively (Significant)) with the quality of the audit [8]. The empirical finding made by Bouhawia et al. (2015) is that the test results show that Honesty (Integrity) has a positive effect on the audit research results quality [9].

In addition to empirical evidence and some previous studies, researchers conducted research in the Selayar Archipelago District because the Selayar Archipelago Government was 6 times in a row, namely during the administration period 2005 - 2010 and the $2011-2015$ administration the results of audit opinions issued by the Supreme Audit Board ( BPK) South Sulawesi Province does not give an opinion.

\subsection{Audit Theory}

According to Mautz and Sharaf (1961), Theory Audit is a guide to conduct audit normative [10]. Auditor has to comply with generally accepted standards and regulations to conduct a quality audit. Audit quality is measurement using generally accepted audit standards and regulations.

\subsection{Quality Audit}

Quality results of audits occur when the examiner carrying out their duties have to carry out appropriate audit standards and code ethics of the accountant's. A quality audit also defined as the characteristic or a description of the practice and the result of the examination in accordance with auditing standards and control standard of quality that measurement function on the professional duties and responsibilities of Audit (Auditor). Some good work accomplished than the criteria set relating to Quality audit.

\subsection{Gender}

According to Fakih (2003), Gender is the character that attached to men and women who are constructed socially and culturally [11]. Research conducted by Jamilah et al. (2006) that women usually have a higher level of moral judgment than men. Moral consideration in question is a step in making decisions and information on auditing client companies [12].

\subsection{Level of education}

General audit standards emphasize the personal qualities of an Auditor must-have, namely:

a. Having adequate technical expertise and training, which means having a formal education in accounting, especially mastering audits, getting adequate training, and having to attend continuing professional education,

b. Have an independent mental attitude, and

c. Conduct audits using their professional expertise carefully and thoroughly because formal education and technical expertise and adequate training will create competent auditors. 


\subsection{Honesty (Integrity)}

Sukriah in Harjanto (2014: 33) states that which public trust and is a benchmark for members on testing all their decisions, is the definition of honesty (Integrity). The Auditor must be honest, transparent, brave, wise and responsible in conducting the Audit. Honesty is an indicator for Examiners (Auditors) who have competence. Honesty (Integrity) is the quality that underlies public trust and is a benchmark (benchmark) to the Inspector (Auditor) on testing all the decisions they make [13]. Sukrisno in Yusuf (2014: 6), stated four indicators of honesty behavior (Integrity), namely [14]:

a. Understand and recognize behavior in accordance with the code of ethics

b. Take action that is consistent with values and beliefs

c. Acting on value even though it is difficult to do so Acting on value despite significant risks or costs

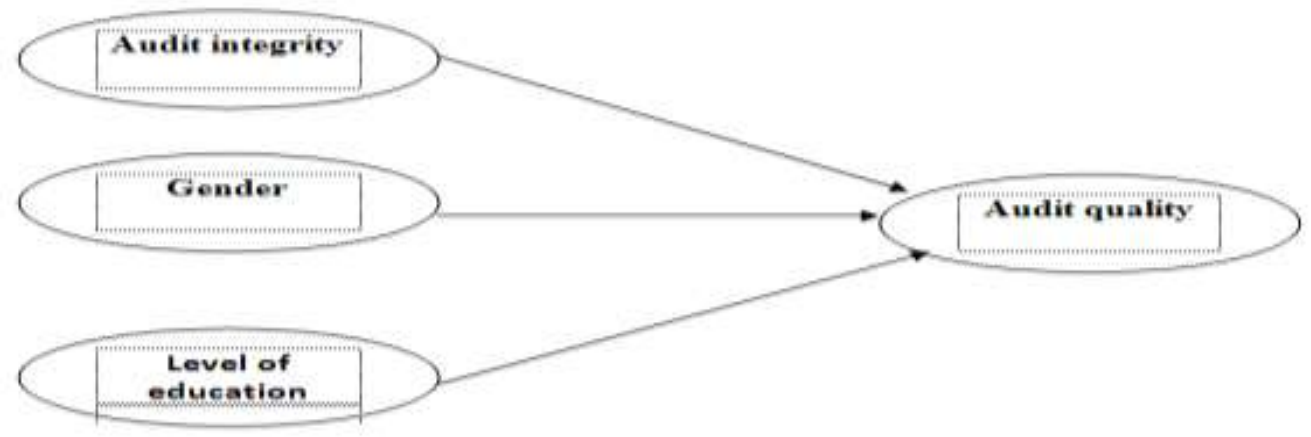

Fig.1. Conceptual Framework

\subsection{Research Hypothesis}

Research conducted by Gold et al. (2009) said female examiners were less competent than male auditors [6]. Another opinion says Inspector (Auditor)) women tend to be more accurate, detail and be more trustworthy and honest. Then research conducted by Ittonen and Peni (2009) provides support for the idea that gender auditors are systematically linked to audit quality [7].

Ocak (2018) said that the main estimation results show that the busyness of the Auditor education level of the Auditor (Auditor) is negatively related positively (significant) with the quality of the audit. The formal level of education of the Auditor minimizes the negative effect of the work of the Auditor on the quality of the Auditor. Also, I find that the negative effect of the busyness of the Auditor on the quality of the audit is clearer in the case of the less educated Auditor [8]. Results of research conducted by Bouhawia et al. (2015) found that the results of the test showed that Honesty (Integrity) has influence is positive (significant) towards quality audit results. Based on this, the hypothesis that was built was [9]:

$\mathrm{H}_{1}$ : Honesty (integrity) examiner (auditor) has a positive (significant) effect on audit quality.

$\mathrm{H}_{2}$ : Gender has a positive effect (significant) on audit quality.

$\mathrm{H}_{3}$ : Education level has a positive effect (significant) on quality audits. 


\section{Research Methodology}

\subsection{Types of research}

Quantitative research used in this research design. This study uses variables, namely Integrity Auditor, gender, and formal education level, are independent variables. Meanwhile, the dependent variable in this study is audit quality.

\subsection{Population and Sampling Techniques}

The study used a population of Auditors working in the Selayar Islands Regency Inspectorate Office with a total of 40 Auditors. The number of samples that followed the total population was less than 100, as many as 40 questionnaires were distributed, and as many as 37 questionnaires were returned. Method convenience sampling was used as a sampling technique. The convenience sampling method is used because the researcher has the freedom to choose a sample quickly from population elements whose data is easily obtained by the researcher.

\subsection{Data analysis technique}

Analysis of the data used in this study is (1) quality test data consisting of validity and reliability tests, (2) hypothesis testing using multiple linear regression tests with a classic assumption test consisting of normality test, multicollinearity test, heteroscedasticity test, and test autocorrelation.

\section{Result and Discussion}

The results of normality test data use Asymp statistical figures. Significant (2 -tailed) is higher than 0.05 for the Kolmogorov-Smirnov $\mathrm{Z}$ statistic. Based on the normality test criteria, the data are normally distributed when the significant value is higher than 0.05; an Asymp number is shown. Significant ( 2 - tailed) of 0.484 can be seen in Table 1.

Table 1. Normality Test Results.

\begin{tabular}{llr}
\hline \multicolumn{2}{c}{ Kolmogorov-Smirnov One Sample Test. } \\
\hline $\mathrm{N}$ & & Nonstandard Residuals. \\
Normal & Means & 37 \\
Parameter a, b & Std. Deviation & 0000000 \\
The Most & Absolute & 2.81427643 \\
Extreme & Positive (significant) & .138 \\
Difference & Negative & .138 \\
Kolmogorov-Smirnov Z & -124 \\
Asymp. Sig. (2-tailed) & .838 \\
A test distribution is Normal & .484 \\
b. Calculated from data & \\
\hline
\end{tabular}

Source: Data processed (2019) 
This shows that the distribution of gender data, education level, honesty (Integrity) of the Auditor, and the quality of the audit is normally distributed. In Table 2 the results of multicollinearity testing use the Variance Inflation Factor. (VIF) Shows the VIF value of each independent variable is less than 10, namely 1.020 for the Auditor (Integrity) variable, 1.013 for the Gender variable, and 1.020 for the Auditor Education level variable (Auditor). The tolerance value is greater than 0.1 , which is 0.980 for the Auditor (Integrity) variable, 0.987 for the Gender level variable, and 0.980 for the education level variable.

Table 2. Multicollinearity Test Results

\begin{tabular}{lccl}
\hline Model & \multicolumn{2}{c}{ Collinearity Statistics } & Information \\
& Tolerance & VIF & \\
\hline (Constant) & .980 & 1.020 & Non Multicollinearity \\
X1 & .987 & 1.013 & Non Multicollinearity \\
X2 & .980 & 1.020 & Non Multicollinearity \\
X3 & &
\end{tabular}

Source: Data processed (2019)

Based on tolerance and VIF values, the correlation between independent variables can be said to have a weak correlation. Thus among the independent variables, no correlation or multicollinearity did not occur in the linear regression model. The results of heteroscedasticity testing using the Glejser test show that the significance value between the independent variable and absolute residue is greater than 0.05 , which is 0.432 for the gender variable, 0.955 for the educational level variable, and 0.00 for the Auditor (Integrity) variable smaller than 0.05 shown in Table 3. Thus, no heteroscedasticity problems were found in the regression model.

Table 3. Heteroscedasticity Test Results.

\begin{tabular}{llrrrrr}
\hline Model & \multicolumn{2}{c}{ Non-Standard Coefficients } & Standard Coefficient & T & Sig. \\
& \multicolumn{1}{c}{ B } & Std. Error & Beta & & \\
\hline \multirow{4}{*}{ (Constant) } & 12.718 & 4.541 & & & 2.801 & .008 \\
1 & X1 & .515 & .108 & .643 & 4.769 & .000 \\
& X2 & .787 & .991 & .107 & .795 & .432 \\
& X3 & .064 & 1.138 & .008 & .057 & .955 \\
\hline
\end{tabular}

Source: Data processed (2019)

There are three (3) hypotheses proposed in this study. Multiple linear regression analysis is used in hypothesis testing. The impact of the determination coefficient analysis can be seen in Table 4, the Adjusted R Square value obtained was 0.359 .

Table 4. Determination Coefficient Test Results

\begin{tabular}{llrrr}
\hline Model. & $\mathrm{R}$ & R. Square & Adjusted R. Square & Standard Estimated Error \\
& & & & \\
\hline 1 & $.642^{\mathrm{a}}$ & .412 & .359 & 2.93942 \\
\hline Source: Data processed (2019)
\end{tabular}


This shows that the quality (quality) of the audit, can be described together with changes in the variable Honesty (Integrity) Examiner (Auditor), Gender, and the level of education of the Examiner (Auditor) of $35.9 \%$, while the remaining $64.1 \%$ by other factors. The results of multiple regressions between the Integrity Auditor (X1), Gender (X2), the Auditor's education level (X3) to the regional audit quality (Y) can be seen in Table 5.

Table 5. Recapitulation of Results of Analysis of Multiple Linear Regression Equations

\begin{tabular}{|c|c|c|c|c|c|}
\hline \multirow[t]{2}{*}{ Model } & \multicolumn{2}{|c|}{ Non-Standard Coefficients } & \multirow{2}{*}{$\begin{array}{c}\text { Standard Coefficient } \\
\text { Beta } \\
\end{array}$} & \multirow[t]{2}{*}{$\mathrm{T}$} & \multirow[t]{2}{*}{ Significant } \\
\hline & B & Standard Error & & & \\
\hline (Constant) & 12.718 & 4.541 & & 2.801 & 008 \\
\hline $\mathrm{X} 1$ & .515 & .108 & 643 & 4.769 & 000 \\
\hline $\mathrm{X} 2$ & .787 & .991 & 107 & .795 & 432 \\
\hline X3 & .064 & 1.138 & 008 & 057 & 955 \\
\hline
\end{tabular}

Source: Data processed (2019)

The multiple linear regression equation models based on table 5, namely:

$$
Y=12,718+0.515 X_{1}+0.787 X_{2}+0.064 X_{3}
$$

See the description shown in the model regression equation that, a decision that is made is as follows:

1. The regression coefficient for the gender variable (X1) is 0.515 ; the direction of the coefficient is positive (significant), which shows that gender has a Significant relationship on audit quality. Positive influence (significant) indicates that the relationship of gender and audit quality (quality) is unidirectional. It acquired a significance level of less than 0.05 because the value of $t$ count obtained at 4.769 . This can be concluded that there is a significant relationship between genders to audit quality. So, there is a positive and significant influence between the sexes on audit quality.

2. The regression coefficient for the Auditor (X2) Honesty (Integrity) variable is 0.787 , the direction of the positive coefficient (Significant), which indicates that the Auditor Honesty (integrity) has a positive (Significant) effect on the audit quality. Positive influence (significant) show that the relationship between the Honesty of the auditor and of the quality audit is one way. Based on Table 5 , the $t$ count of 0.795 was obtained with a significance level of less than 0.05 . It can be concluded that there is a significant influence between the Honesty (Integrity) of the auditor on the quality of the audit. So, there is a positive (significant) and significant relationship between Honesty (Integrity) of the examiner (auditor) of the quality audit.

3. The regression coefficient for the Auditor's formal education level variable is 0.064 , the efficient positive direction (significant) which shows that the Auditor's formal education level has a positive (Significant) effect on the audit's quality. Positive influence (Significant) explains that the level of formal education of the Auditor and the quality of the audit is to have a direct relationship. If the level of formal education of the Auditor is higher, the quality of the audit will also be higher. Based on Table 5, the $t$ count of 0.057 was obtained with a significance level of less than 0.05 . It can be concluded that there is a significant influence between the levels of formal education of the Auditor on the quality of the audit. So, there is a significant relationship between the formal education level of the Auditor and of the quality audit. 
Independent variables have a significant relationship to the quality of audit results simultaneously and partially of the three variables. The most dominant variable that affects the quality of audit results is honesty (Integrity) audit because it has the largest coefficient and t arithmetic.

The results of this research indicate that the honesty (Integrity) of the Auditor on the quality of the audit results is significant (0.000), also positively related (significant). The result is related to the Auditor's understanding of behavior according to the code of ethics. Auditor Performs Actions Consistent with his Values and Beliefs, even though it is difficult to do and the Auditor acts based on Value even though Risk or Cost is quite large, this inline the research conducted by Pujiastuti (2014) that honesty has a positive parameter on the quality of the audit, meaning that the higher the level of honesty (Integrity) the better quality of the audit. Honesty (Integrity) is an honest, brave, wise attitude and the responsibility of the auditor on carrying out audits.

The result of gender towards the audit quality has a significant relationship (0.432) and a positive correlation (significant). This is related to the experience of conducting audits, following general standards, the involvement of leaders, and the involvement of the audit committee. According to Fakih (2003) states Gender is a trait that is inherent in men and women who are instructed socially and culturally [11]. According to the theory of balance emphasizes the concept of partnership and harmony in the relationship between women and men. According to Meyer \& Levy in Jamilah (2007) states that female auditors tend to be more careful in processing information by using complete information and re-evaluating that information and not easily giving up. Women are relatively more efficient than men in accessing information [12].

The education level of the auditor on the results of the quality of the audit has a significant effect (0.955) and is positively correlated (significant). This research is in line with Cheng et al. in Pebryanto (2013), who states that the educational achievements of the auditor can improve the quality of government audits, as well as educational attainment, to guarantee the quality of the workforce. Empirically the results of this study are consistent with the results of previous studies conducted by Pebryanto (2013), which shows that the level of education of the auditor has a positive (significant) and significant effect on the quality of the audit [15].

\section{Conclusion}

1. Honesty (integrity) auditor has a relationship that is positive (significant) towards quality audit results.

2. Gender me have a relationship that is positive (significant) towards quality audit results.

3. The education level of the auditor has a positive (significant) relationship to the quality audit results.

As a result of the t-test, the honesty (integrity) variable of the Auditor has the calculated t value and the largest beta coefficient. Therefore, the honesty (integrity) examiner (auditor) variable has the most powerful influence than other variables so that the honesty (integrity) variable has the strongest influence on the quality of audit results.

Based on empirical evidence in this study, there are a number of suggestions that can be given to future researchers.

1) For the auditor, it is necessary to increase the honesty (integrity) of the auditor and the level of education of the auditor to improve the quality of the audit results. 
2) For further researchers, can develop this research by adding other variables or can examine other factors that can affect the quality of audit results.

\section{References}

[1] Mgbame. C.O.: Gender factor in audit quality: Evidence from Nigeria. Research Journal of Finance and Accounting. vol. 3, no. 4, pp. 81-88 (2012).

[2] Moizer. P.: Auditor Repution: The International Empirical Devidence. Internasional journal of Auditing (IJA). vol. 1, no. 1, pp. 61-74 (1997).

[3] Hay. D and Knechel. W.R.: Audit Market, Fees and Productioan: Towards and Integrated View of Emperical Audit Research. Journal of Acoounting Leterature. vol. 29 (2010).

[4] Houghton. K.A and Jubb.C. A.: Auditor selection: what influences decisions by listed companies?. Australian Accounting Review. vol. 13, no. 31, pp. 67-72 (2003).

[5] Hardies. K, Breesch. D, and Branson. J.: Are female auditors still women? Analyzing the sex differences affecting audit quality. Analyzing the Sex Differences Affecting Audit Quality (January 14, 2010) (2010).

[6] Gold. A, Hunton. J, and Gomaa. M. The Impact of Client and Auditor Gender on Auditor's Judgments (retracted). Accounting Horizon. vol. 23, no. 1, pp. 1-18 (2009).

[7] Ittonen. K and Peni. E.: Auditor's gender and audit fees.: International Journal of Auditing. vol. 16, no. 1, pp. 1-18 (2012).

[8] Ocak. M.: The impact of auditor education level on the relationship between auditor busyness and audit quality in Turkey. Cogent Business \& Management. vol. 5, no. 1, p. 1517588 (2018).

[9] Bouhawia. M. S, Irianto. G, and Baridwan. Z.: The Effect of Working Experience, Integrity, Competence, and Organizational Commitment on Audit Quality (Survey State Owned Companies in Libya). IOSR Journal of Economics and Finance (IOSR-JEF). vol. 6, no. 4, pp. 60-67 (2015).

[10] Mautz. R and Sharaf. A. H.: The Filosofi Of Auditing. America Acocounting Association (1961).

[11] Fakih. M.: Analisis Gender dan Transformasi Sosial. Pustaka Pelajar: Yogyakarta (2003).

[12] Jamilah. S, Zaenal. F, and Grahita. C.: Pengaruh Gender, Tekanan Ketaatan, dan Kompleksitas Tugas terhadap Audit Judgment. Simposium Nasional Akuntansi X Unhas Makassar (2006).

[13] Harjanto.: Pengaruh Kompetensi, Independensi, Objektivitas, Akuntabilitas Dan Integritas Terhadap Kualitas Audit Dengan Etika Auditor Sebagai Variabel Moderasi. Fakultas Ekonomika Dan Bisnis Universitas Diponegoro Semarang (2014).

[14] Yusuf.: Pengaruh Kompetensi, Objektivitas Dan Integritas Auditor Terhadap Kualitas Hasil Kerja Auditor. Universitas Negeri Padang (2014).

[15] Pebryanto. S.: Pengaruh Tingkat Pendidikan Formal, Pengalaman Kerja, Tingkat Kualifikasi Profesi, Continuing Professional Development Terhadap Kualitas Audit di Badan Pemeriksa Keuangan (BPK) Ri Perwakilan Sulawesi Selatan. Universita Hasanuddin Makasar (2013). 